\title{
On the collections of Indo-Australian Spirobolida (Diplopoda) kept in the Zoological Museum of the Moscow State University, Russia. 1. A new species of Arisemolus Hoffman, 1980 from Papua New Guinea
}

\author{
O комлекщиях индо-австралийских Spirobolida (Diplopoda), \\ хранящихся в Зоологическом музее Московского \\ государственного университета (Россия). 1. Новый вид Arisemolus \\ Hoffman, 1980 из Папуа-Новой Гвинеи
}

\author{
S.I. Golovatch ${ }^{1}$, J.-P. Mauriès ${ }^{2}$, N. Akkari ${ }^{3}$ \\ С.И. Головач ${ }^{1}$, Ж.-П. Морьес ${ }^{2}$ Н. Аккари
}

\footnotetext{
${ }^{1}$ Institute for Problems of Ecology and Evolution, Russian Academy of Sciences, Leninsky prospekt 33, Moscow 119071 Russia. E-mail: sgolovatch@yandex.ru

${ }^{1}$ Институт проблем экологии и эволюции РАН, Ленинский проспект, 33, Москва 119071 Россия.

${ }^{2}$ Muséum national d'Histoire naturelle, Département de Systématique et Evolution, 61 rue Buffon, F-75231 Paris Cedex 05, France.

${ }^{3}$ Naturhistorisches Museum Wien, Burgring 7, A-1010 Wien, Austria.
}

KEY WORDS: Millipede, Pachybolidae, taxonomy, new species, New Guinea.

КЛЮЧЕВЫЕ СЛОВА: двупарноногие многоножки, Рachybolidae, таксономия, новый вид, Новая Гвинея.

ABSTRACT. Arisemolus kurtschevae sp.n. is described as the first species of the genus to be reported from mainland (and inland) Papua New Guinea. The new species differs from all three other accepted congeners that range from the Mariana and Caroline islands in Micronesia, through the Bismarck Archipelago and Vanuatu in Melanesia, to western New Guinea, Indonesia, primarily by certain details of gonopodal structure, in particular the considerably longer/higher sternite of the anterior gonopods and the shape of the distal part of the posterior gonopods. New illustrations are provided for both A. tamicus (Attems, 1914) (the type species) and A. ralumensis obscuratus (Attems, 1914), the latter being formally synonymized with $A$. ralumensis ralumensis, syn.n. Lectotype designation is made for $A$. tamicus.

How to cite this article: Golovatch S.I., Mauriès J.P., Akkari N. 2020. On the collections of Indo-Australian Spirobolida (Diplopoda) kept in the Zoological Museum of the Moscow State University, Russia. 1. A new species of Arisemolus Hoffman, 1980 from Papua New Guinea // Arthropoda Selecta. Vol.29. No.3. P.309-315. doi: 10.15298/arthsel. 29.3.02

РЕЗЮМЕ. Описан новый вид Arisemolus kurtschevae sp.n., первый представитель рода из материковой (и внутренней) части Папуа - Новой Гвинеи. Новый вид отличается от остальных трех принятых видов и распространенных от Марианских и Каролинских островов в Микронезии, архипелагов Бисмарка и Вануату в Меланезии до западной части Новой Гвинеи (Индонезия), прежде всего, определенными деталями строения гоноподов, в особенности значительно более длинным/высоким стернитом передних гоноподов и формой дистальной части задних гоноподов. Представлены новые иллюстрации как для A. tamicus (Attems, 1914) (типовой вид), так и для A. ralumensis obscuratus (Attems, 1914), притом последний подвид формально сведен в синонимы к A. ralumensis ralumensis, syn.n. Для A. tamicus установлен лектотип.

\section{Introduction}

The collections of the Zoological Museum of the Moscow State University (ZMUM), Russia are rich and varied, contain a quite large and diverse material belonging to the millipede order Spirobolida, with samples from all families (Pachybolidae, Pseudospirobolellidae, Rhinocricidae and Spirobolellidae) that occur in the Indo-Australian region [Jeekel, 2001]. The samples were collected in 1976 and 1977 by Yuriy I. Chernov and Galina F. Kurcheva during two expeditions on board the research vessels "Kallisto" and "Dmitry Mendeleyev", respectively, to several islands and archipelagos in the southwestern Pacific.

To determine and describe the new species, old literature and type specimens deposited in various natural history museums must be checked and studied. Chamberlin [1920] produced a monograph that contained descriptions of several dozen new genera and a few hundred new species of millipedes (Diplopoda) without any single illustration. This strongly hampers species determinations and generally impedes any progress in the taxonomy of millipedes in the southwestern Pacific. Most, if not all, of the types of Chamberlin [1920] are still kept in the Museum of Comparative Zoology (MCZ) at Harvard, Massachusetts, U.S.A., 

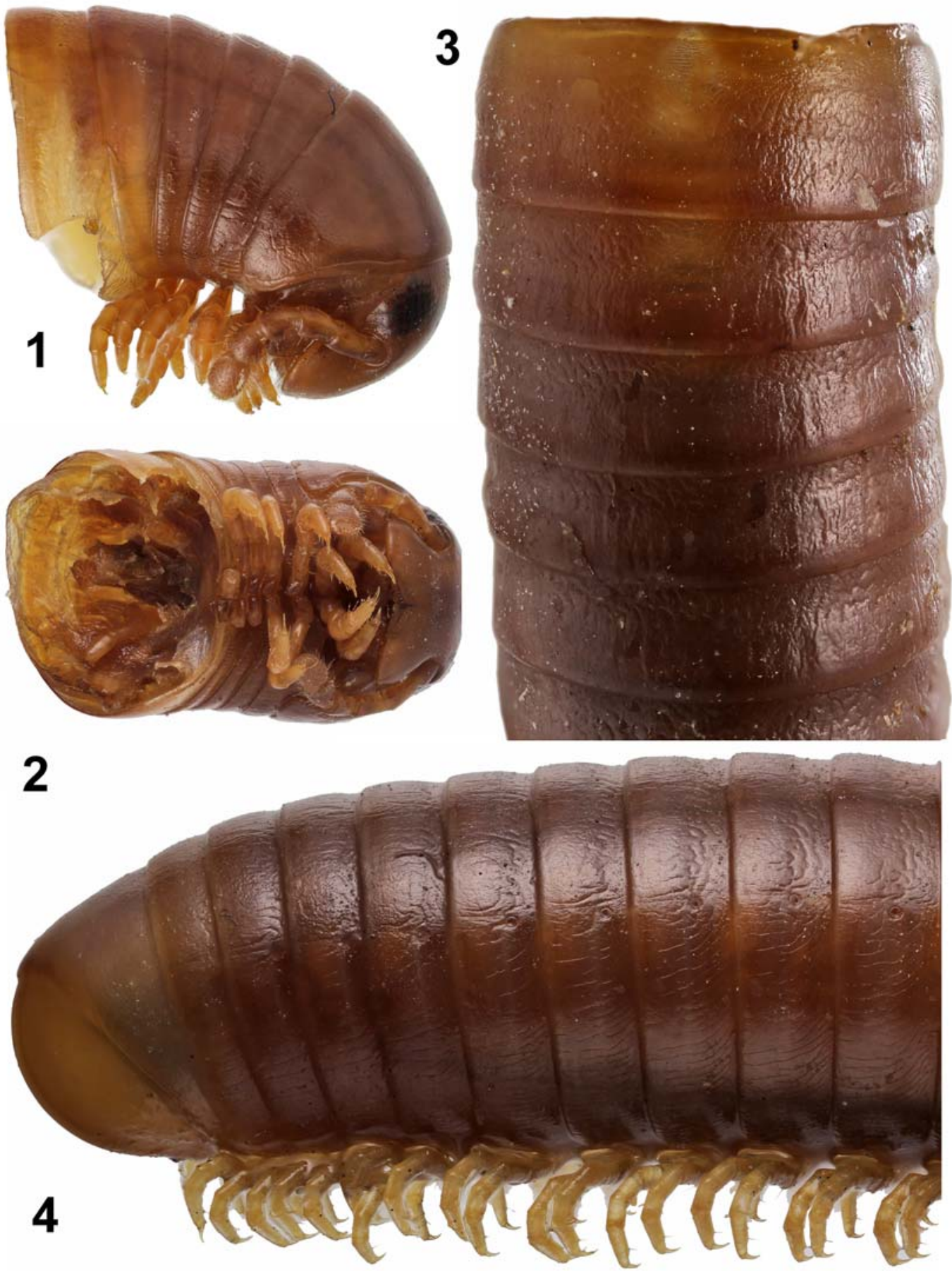

Figs 1-4. Arisemolus kurtschevae sp.n., $0^{7}$ paratype. 1-2 - anterior part of body, lateral and ventral views, respectively; 3 midbody segments, dorsal view; 4 - posterior part of body, lateral view. Pictures by K. Makarov, not taken to scale.

Рис. 1-4. Arisemolus kurtschevae sp.n., паратип O’. 1-2 - передняя часть тела, соответственно сбоку и снизу; 3 - среднетуловищные сегменты, сверху; 4 - задняя часть тела, сбоку. Фотографии К.В. Макарова, сняты без масштаба.

and are appealing for a serious revisionary work. In fact, only a few of these types have hitherto been revised, allowing for only a minor fraction of his taxa to be properly recognized and considered in the current millipede taxonomic context. As a first step, the MCZ diplopod type collection could perhaps be catalogued, digitalized and made available for researchers. The same actually applies to most of the other major museum collections of Diplopoda worldwide, i.e. the museums in Berlin, Hamburg, London, Munich, Paris, New York, Washington D.C. etc. [Sierwald, Reft, 2004]. A few museums, apparently depending on the goodwill 

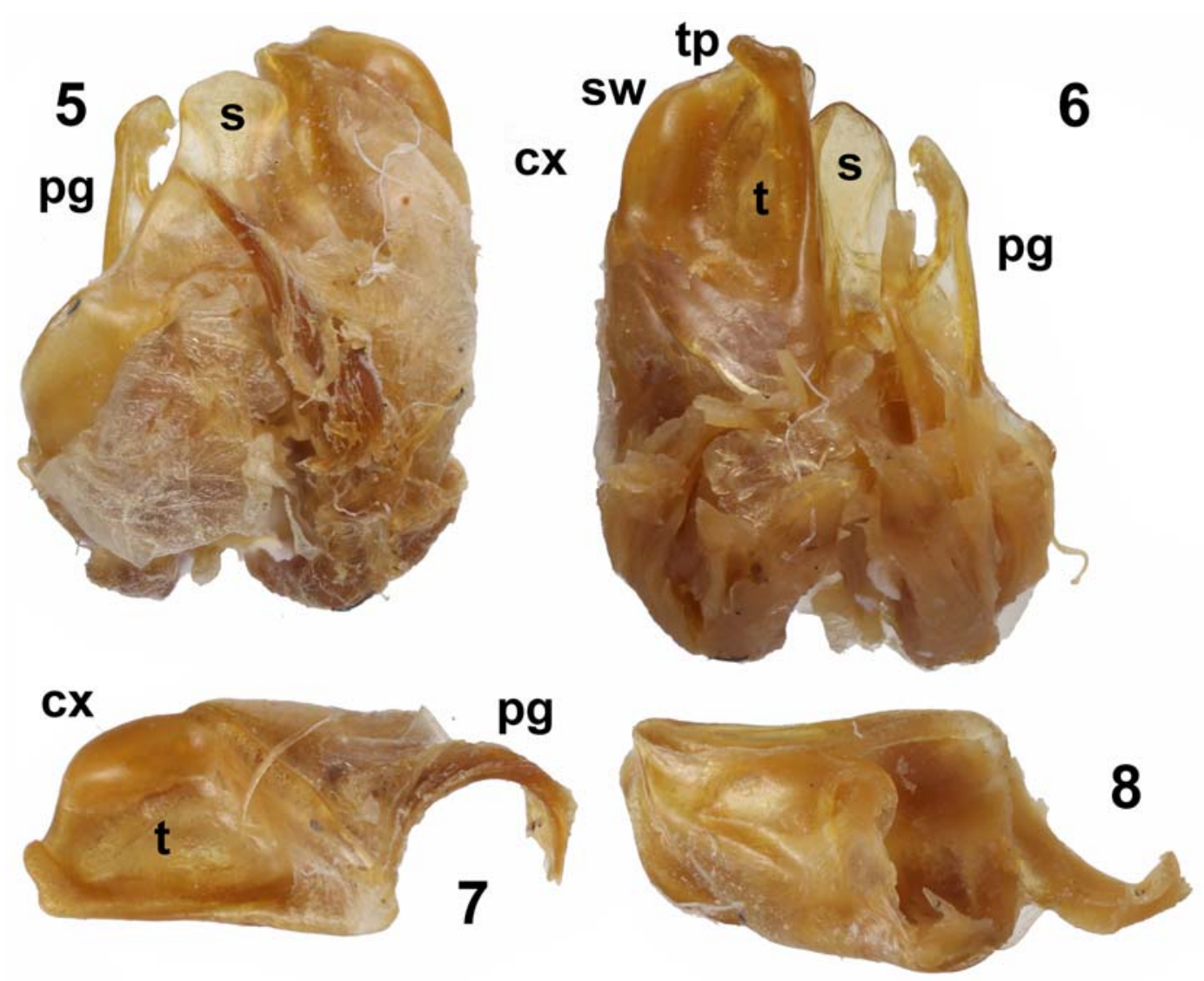

Figs 5-8. Gonopods of Arisemolus kurtschevae sp.n., $0^{7}$ paratype. 5-6 - right anterior and left posterior gonopods, anterior and posterior views, respectively; 7-8 - left anterior and right posterior gonopods, posterior and anterior views, respectively. Pictures by K. Makarov, not taken to scale. Designations explained in text.

Рис. 5-8. Гоноподы Arisemolus kurtschevae sp.n., паратип 07. 5-6 - правый передний и левый задний гоноподы, соответственно спереди и сзади; 7-8 - левый передний и правый задний гоноподы, соответственно сзади и спереди. Фотографии К.В. Макарова, сняты без масштаба. Объяснения обозначений даны в тексте.

of the collection keeper involved, provide pictures of the requested types or other specimens. The Munich Museum is particularly helpful in this respect. The Senckenberg Museum in Frankfurt a.M. has recently launched an electronic catalogue of all identified Myriapoda, <http://sesam.senckenberg.de/page/index.htm>. The Natural History Museum in Vienna (NHMW) is outstanding and compares especially favourably in much of its diplopod type collections having been catalogued, digitalized, and available upon request, while only the Berlin, Chicago and Hamburg collections enjoy modern printed catalogues.

By necessity, only a careful, slow and methodic approach is realistic from our side to assess the ZMUM collections. The present paper is the first in a series devoted to a taxonomic treatment of the ZMUM collections and it puts on record a new species of the family Pachybolidae from New Guinea. Jeekel's [2001] catalogue of the Indo-Pacific Spirobolida is still very useful and almost complete, supplemented since only through the description of a new genus and species of Pachybolidae from Western Australia [Hoffman, 2003], three new species of Spirobolellus Pocock, 1894 from eastern Australia [Jeekel, 2002, 2003], and the synonymization of one genus and two species of Spirobolellidae from New Zealand [Johns, 2010].

\section{Material and methods}

All new material treated below is deposited in the ZMUM. Colour pictures were obtained with a Canon EOS 5D digital camera and stacked using Zerene Stacker software. Type material housed in the NHMW is also studied and documented for comparison with the new species, using a Nikon DS-Ri-2 camera mounted on a Nikon SMZ25 stereo microscope using NIS-Elements Microscope Imaging Software with an Extended Depth of Focus (EDF) patch.

The classification, however deficient, follows that of Jeekel [2001] and Minelli [2015], allowing for catalogue sections to be omitted as redundant.

\section{Taxonomic part}

\section{Family PACHYBOLIDAE Arisemolus Hoffman, 1980}

SYNONYM: Arisemus Attems, 1953, proposed invalidly without a type species [Attems, 1953], validated later 

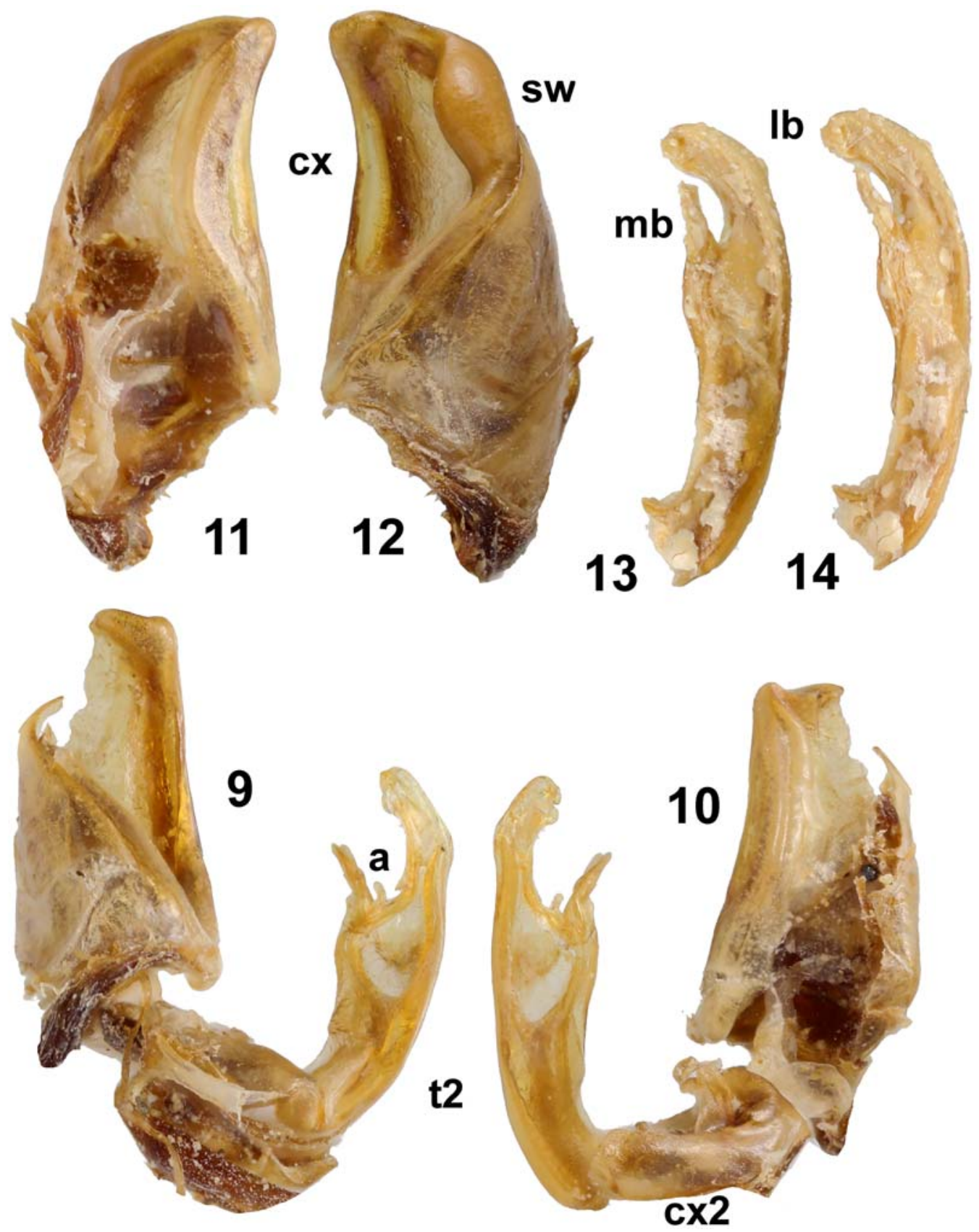

Figs 9-14. Gonopods of Arisemolus kurtschevae sp.n., $0^{7}$ paratype. 9-10 - right anterior and posterior gonopods (anterior gonopod coxa damaged), anterior and posterior views, respectively; 11-12 - left anterior gonopod, anterior and posterior views, respectively; 1314 - left posterior gonopod telopodite, posterior and anterior views, respectively. Pictures by K. Makarov, not taken to scale. Designations explained in text.

Рис. 9-14. Гоноподы Arisemolus kurtschevae sp.n., паратип О7. 9-10 - правый передний и задний гоноподы (тазик переднего гонопода поврежден), соответственно спереди и сзади; 11-12 — левый передний гонопод, соответственно спереди и сзади; 13-14 телоподит левого заднего гонопода, соответственно сзади и спереди. Фотографии К.В. Макарова, сняты без масштаба. Объяснения обозначений даны в тексте.

[Hoffman, Keeton, 1960], but, being preoccupied, renamed as Arisemolus [Jeekel, 1971, 2001; Hoffman, 1980].

TYPE SPECIES: Trigoniulus tamicus Attems, 1914

DIAGNOSIS: A genus of Pachybolidae rather poorly delimited against a number of genera placed close to Trigoniulus Pocock, 1894 [Minelli, 2015], characterized by the posterior gonopod coxite being supplied with two basal internal chambers, and a bipartite and clearly curved telopodite showing a few small, mesal lobules or spines distal to its main mesal branch which is relatively small, slender, parallel-sided, microdentate or scaly, located near the telopodite's midway. 
Included species:

Arisemolus laminatus (Takakuwa, 1942)

Arisemolus ralumensis (Attems, 1914)

Arisemolus tamicus (Attems, 1914)

Arisemolus kurtschevae sp.n.

REMARKS. This small genus has hitherto been considered as containing only four accepted species or subspecies [Jeekel, 2001]. They range from the Mariana and Caroline islands in Micronesia (A. laminatus (Takakuwa, 1942), see Takakuwa [1942]), through the Bismarck Archipelago and Vanuatu in Melanesia (A. ralumensis ralumensis (Attems, 1914) and A. ralumensis obscuratus (Attems, 1914), see Attems [1914] and Carl [1926]), to western New Guinea, Indonesia (A. tamicus (Attems, 1914), see Attems [1914]).

First Chamberlin [1920] only listed the few names of Attems [1914] known by then, but later [Chamberlin, 1945, 1947] he did manage to add to the confusion by describing two species from Micronesia, both of which Jeekel [2001] synonymized with $A$. laminatus. The status of $A$. laminatus likewise may well be questioned vis-à-vis $A$. ralumensis, as both show particularly similar gonopods and vast distributions.

Below is the first Arisemolus to be reported from mainland (and inland) Papua New Guinea.

\section{Arisemolus kurtschevae sp.n.}

Figs 1-14.

HOLOTYPE $\sigma^{7}$ (ZMUM), Papua New Guinea, Morobe Prov., Wau, ca. $2000 \mathrm{~m}$ a.s.1., montane tropical rain forest near road, litter, 19.II.1977, G.F. Kurcheva leg.

PARATYPES: $3 \sigma^{7} \sigma^{7}, 4$ Oᄋ, 5 juv. (ZMUM), same data, together with holotype.

NAME. To honour the late Dr. Galina Fedorovna Kurcheva, the collector.

DIAGNOSIS. Differs from all other species of Arisemolus primarily by certain details of gonopodal structure, in particular the considerably longer/higher sternum of the anterior gonopods and the shape of the distal part of the posterior gonopod telopodites, in which the inner branch is unusually small and slender (Figs 5-14).

DESCRIPTION. Body of complete adult specimens $\left(\sigma^{7}\right.$, +) 30-35 mm long, width or height of midbody segments 3.0-3.7 mm, adults with 41-45+T segments, apodous segments in front of $\mathrm{T}$ absent, but a few present in juveniles. Coloration usually uniformly red-brown (Figs 1-4), head and collum often slightly lighter; a faint pattern/cingulation sometimes traceable due to slightly darker, brown or redbrown metazonae. Eye patches dark brown to brown. Legs light brown.

Body cylindrical, postcollum contriction very faint (Fig. 2 ). Head as usual, three small central teeth at fore margin of and a superficial, fine, axial suture on labrum, with $7-8+7-8$ labral and 2+2 supralabral setae. Eye fields subcircular, small, flat (Fig. 1), isthmus ca. 2x diameter of eye patch (Fig. 2), in holotype each eye patch composed of 41-42 ommatidia arranged in six vertical rows $($ ca. $7+8+8+8+7+3)$. Antennae short and clavate, in situ stretched laterally behind until caudal margin of collum; in length, antennomere $2=6>$ $3=4=5>1=7 ; 8^{\text {th }}$ with four small apical cones (Figs 1,2 ). Tegument bare, almost smooth, mostly shining and very delicately reticulate, in places faintly striolate (Figs 1-4). Collum broadly rounded and clearly bordered both anteriorly and laterally, but considerably more narrowly rounded and subangulate caudolaterally (Fig. 1). Midbody segments/ rings devoid of evident sutures between zonae, very poorly constricted only between meso- and metazonae; the latter finely and longitudinally striolate, more clearly, densely and regularly so ventrolaterally, increasingly sparsely, irregularly/confusedly and incompletely so laterad until just above ozopore, striolations being almost obliterated further dorsad; mesozonae similarly finely striolate, but striolations first arcuated closer to metazonae, but then increasingly subvertical, also declining towards ozopore region; prozonae especially finely and densely striolate, striolations being subvertical and extended across dorsum (Figs 1-4). Scobinae absent. Ozopores small round disks lying near fore margin of metazonae on all leg-bearing segments starting with segment 6 (Figs 1, 4). Telson (Fig. 4) as usual, epiproct flat, caudally rounded and very small; paraprocts strongly and regularly convex, smooth, not bordered along caudal margin, with only a small and inconspicuous gutter between both valves; hypoproct subreniform. Only $\sigma^{7}$ segment 7 clearly swollen ventrally, a complete ring due to a strong ventral bridge in caudal half.

Legs short and slender, ca. 2/3 as long as midbody height, each usually with a spine below and above claw; only $\sigma^{r}$ legs 1 and 2 somewhat shorter and devoid of ventral sole pads on tarsi, while all following tarsi with evident sole pads; $\sigma^{7}$ coxae 3-7 with evident ventral tubercles, that on each of coxae 3 and 4 higher, rounded cones directed ventrocaudally, that on each of coxae 5-7 lower, flat and transversely squarish (Fig. 2).

Gonopods (Figs 5-14) typical of Pachybolidae. Anterior gonopods with a strong, broad, median, subtriangular, apically roundly subtrapeziform, sternal process (s), the latter only slightly shorter than both coxa (cx) and telopodite (t) with its small, apical, rounded, laterally directed process (tp); cx the largest, roundly squarish, with a characteristic apicolateral swelling (sw) subtending a slender $\mathbf{t}$ on caudal side; posterior gonopods (pg) connected by a sclerotized sternum, each gonopod consisting of a short subcylindrical coxa (cx2) and a slender, longer, bipartite telopodite (t2); apicolateral branch (lb) the largest, slightly curved, densely microtuberculate, apically rounded; mesal branch (mb) much shorter, finger-shaped, apically subtruncate; a small denticle present between $\mathbf{l b}$ and $\mathbf{m b}$.

REMARKS. Because gonopodal micropreparations of A. ralumensis obscuratus (Attems, 1914) and A. tamicus (Attems, 1914) are also available in the NHMW collection, we provide their pictures for comparative purposes. The relevant details of that collection are presented below.

Arisemolus ralumensis var. obscuratus (Attems, 1914) Figs 15-17.

Trigoniulus ralumensis var. obscuratus Attems, 1914: 349.

CURRENT STATUS: Arisemolus ralumensis obscuratus (Attems, 1914) — Jeekel, 2001: 58.

TYPE MATERIAL: Syntype, $1 \sigma^{7}$ dissected, gonopods in vial, Neu Pommern, W Küste, Tu Island [Papua New Guinea, New Britain Island, West coast, Tu island], Hamburger Südsee Exp. (NHMW 8537); 1 micro-preparation "Trigonoiulus ralumensis var. obscuratus" including dissected gonopods (NHMW 8370), Neu Pommern N. Küste, [New Britain Island, North coast, "Forsayth island'], Hamburger Südsee Exp., Duncker leg.

COMMENT. Originally described by Attems as a variety of $T$. ralumensis, this name was later listed as a subspecies by Weidner [1960] and has remained treated as such [Jeekel, 2001]. The Hamburg Museum contains $5 \sigma^{7} \sigma^{7}$ syntypes [Weidner, 1960]. As this taxon differs from T. ralumensis only in the lack of a colour pattern [Attems, 1914], 

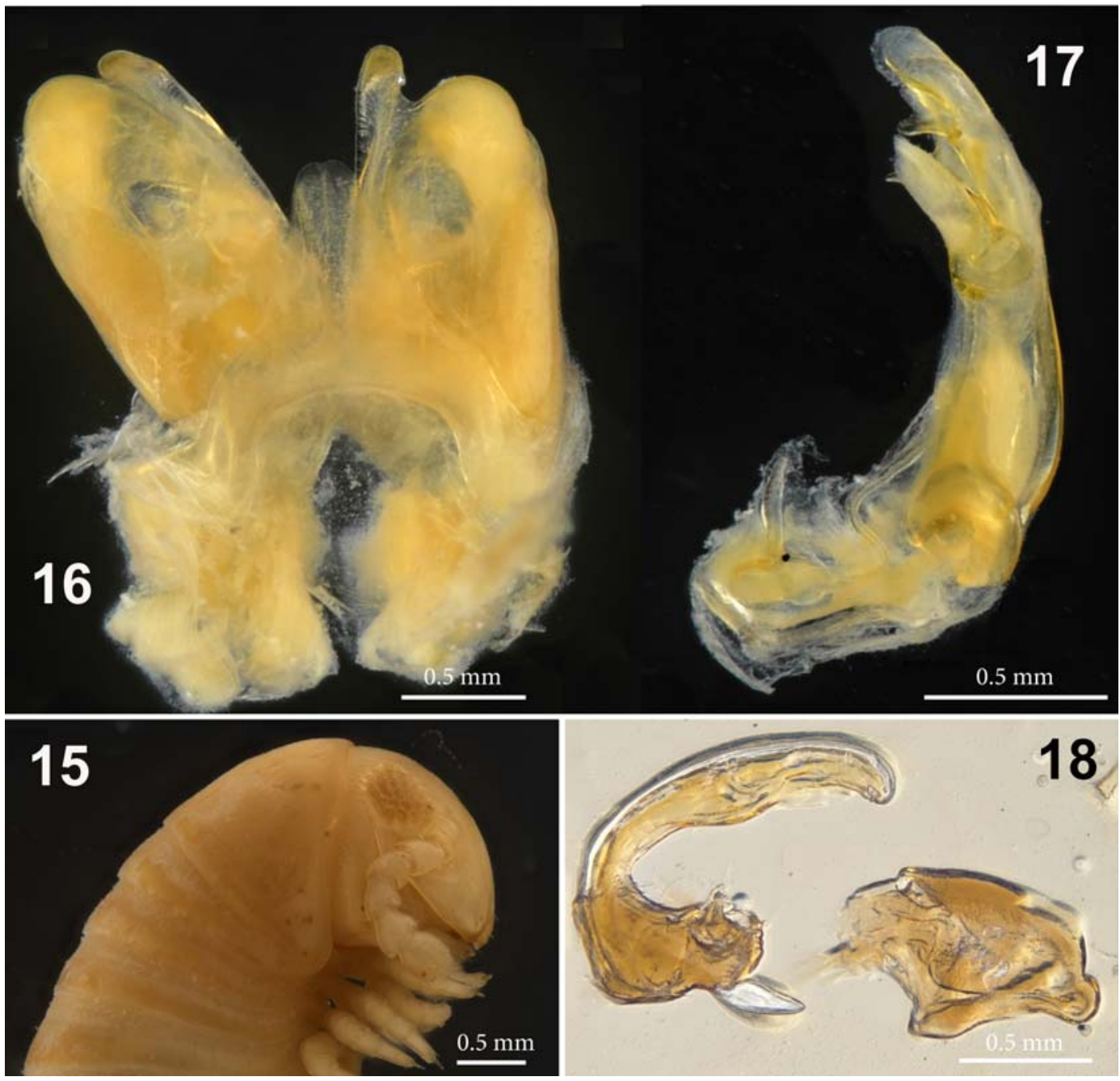

Figs 15-18. Arisemolus ralumensis var. obscuratus (Attems, 1914), O' syntype, NHMW 2403, slide MY8537 (15-17) and Arisemolus tamicus (Attems, 1914), O' lectotype (NHMW 4043) (18). 15 - anterior part of body, lateral view; 16 - anterior gonopods, caudal view; 17 - right posterior gonopod, anterior view; 18 - both gonopods.

Рис. 15-18. Arisemolus ralumensis var. obscuratus (Attems, 1914), синтип О', NHMW 2403, препарат MY8537 (15-17) и Arisemolus tamicus (Attems, 1914), лектотип О' (NHMW 4043) (18). 15 - передняя часть тела, сбоку; 16 - передние гоноподы, сзади; 17 - правый задний гонопод, спереди; 18 - оба гонопода.

we formally synonymize obscuratus with ralumensis ralumensis, syn.n., returning its original status. Figs 15-17 show some of the main structural details of T. ralumensis.

\section{Arisemolus ralumensis (Attems, 1914)}

Trigoniulus ralumensis Attems, 1914: 348-349, Taf. V, Abb. 72-76.

CURRENT STATUS: Arisemolus ralumensis (Attems, 1914) - Jeekel, 2001: 58.

TYPE MATERIAL: Syntype, $1 \sigma^{7}$ dissected, broken into four parts, three legs, Ralum [Papua New Guinea, New Britain Island, East New Britain province, Gazelle peninsula, Kokopo district], don. Berliner Museum, leg. Dahl; 2 micro-preparations, one with anterior and posterior gonopods, and one with legs 3-5 (NHMW 2403), same locality.

COMMENT. Additional types are housed in the Berlin Museum [Moritz, Fischer, 1975].
Arisemolus tamicus (Attems, 1914) Fig. 18.

Trigoniulus tamicus Attems, 1914: 349-350, Taf. IV, Abb. $62-67$.

CURRENT STATUS: Arisemolus tamicus (Attems, 1914) - Jeekel, 2001: 58.

TYPE MATERIAL: Syntype $0^{7}$. One micro-preparation with gonopods, "Trig. tamicus/ Tami Gebiet./ Neu Guinea/ Berlin M.”, Indonesia, New Guinea, Papua province (NHMW 4043).

COMMENT. One $\sigma^{7}$ and 3 + 9 syntypes are in the Berlin Museum collection [Moritz, Fischer, 1975]. Because the $\sigma^{7}$ in Berlin lacks the gonopods, these can easily be presumed as having been retained in the above slide in the NHMW collection (Fig. 18). We designate herewith this $\sigma^{7}$ as the lectotype to secure that the taxon is based on the male. 
Acknowledgements. This study was partly supported by the Presidium of the Russian Academy of Sciences, Program No. 41 "Biodiversity of natural systems and biological resources of Russia".

\section{Compliance with ethical standards}

Conflict of Interest: The authors declare that they have no conflict of interest.

Ethical approval: No ethical issues were raised during our research.

\section{References}

Attems C. 1914. Die indo-australischen Myriopoden // Archiv für Naturgeschichte. Jg.80A. H.4. S.1-398.

Attems C. 1953. Myriopoden von Indochina. Expedition von Dr C. Dawydoff (1938-1939) // Mémoires du Muséum national d'Histoire naturelle, Série A, Zoologie. T.5. Fasc.3. S.133199.

Carl J. 1926. Diplopoden von Neu-Caledonien und den LoyaltyInseln // Sarasin F., Roux J. (eds.). Nova Caledonia, Zoologie. München. Vol.4. L.3. S.369-462.

Chamberlin R.V. 1920. The Myriopoda of the Australian Region // Bulletin of the Museum of Comparative Zoölogy at Harvard College. Vol.64. No.1. P.1-269.

Chamberlin R.V. 1945. On some millipeds from Saipan // Proceedings of the Biological Society of Washington. Vol.58. P.3338

Chamberlin R.V. 1947. On some millipeds from Micronesia // Entomological News. Vol.58. P.41-47.

Hoffman R.L. 1980 (for 1979). Classification of the Diplopoda. Genève: Muséum d'histoire naturelle. $237 \mathrm{pp}$.

Hoffman R.L. 1999. Checklist of the millipeds of North and Middle America // Virginia Museum of Natural History Special Publication 8. P.1-584.

Hoffman R.L. 2003. A new genus and species of trigoniuline milliped from Western Australia (Spirobolida: Pachybolidae: Trigoniulinae) // Records of the Western Australian Museum. Vol.22. P.17-22
Hoffman R.L., Keeton W.T. 1960. A list of the generic names proposed in the diplopod order Spirobolida, with their typespecies // Transactions of the American Entomological Society. Vol.86. P.1-26.

Jeekel C.A.W. 1971 (for 1970). Nomenclator generum et familiarum Diplopodorum // Monografieën van de Nederlandse Entomologische Vereniging. No.5. 412 pp.

Jeekel C.A.W. 2001. A bibliographic catalogue of the Spirobolida of the Oriental and Australian regions (Diplopoda) // Myriapod Memoranda. Vol.4. P.5-104.

Jeekel C.A.W. 2002. Millipedes from Australia, 13: Spirobolellus scheltemai nov. sp., a new millipede from southern Queensland (Diplopoda Spirobolida) // Myriapod Memoranda. Vol.5. P.52-59.

Jeekel C.A.W. 2003. Millipedes from Australia, 15: Spirobolellus (Diplopoda Spirobolida) from Lord Howe Island // Myriapod Memoranda. Vol.6. P.5-13.

Johns P. 2010. Phylum Arthropoda Myriapoda: centipedes, millipedes, pauropods, and symphylans // Gordon D.P. (ed.). New Zealand inventory of biodiversity. Vol.2. Kingdom Animalia. Chaetognatha, Ecdysozoa, ichnofossils. Christchurch, New Zealand: Canterbury University Press. P.90-97.

Minelli A. (ed.). 2015. Treatise on Zoology - Anatomy, Taxonomy, Biology. The Myriapoda. Vol.2. Brill: Leiden - Boston. 482 pp.

Moritz M., Fischer S.C. 1975. Die Typen der Myriapoden-Sammlung des Zoologisches Museums Berlin. I. Diplopoda. Teil 3: Julida, Spirobolida // Mitteilungen aus dem Zoologischen Museum der Humboldt-Universität zu Berlin. Bd.51. H.2. S.199_ 255.

Sierwald P., Reft A.J. 2004. The millipede collections of the world // Fieldiana: Zoology, n.s. No.103. P.1-100.

Takakuwa Y. 1942. Myriapoda of the Micronesia // Kagaku-Nanyo (= Micronesian Science). Vol.5. No.1. P.14-44 [in Japanese and German].

Weidner H. 1960. Die Entomologischen Sammlungen des Zoologischen Staatsinstituts und Zoologischen Museums Hamburg. III. Teil. Chilopoda und Progoneata // Mitteilungen aus dem Hamburgischen Zoologischen Museum und Institut. Bd.58. S.57-104.

Responsible editor K.G. Mikhailov 